\title{
An Education Kit Design for Lightning Protection of a Wind Turbine
}

\author{
Bedri Kekezoğlư ${ }^{1}$, Hasan Can Kılıçkıran ${ }^{2}$, Ibrahim Şengör ${ }^{3}$, Hüseyin Akdemir ${ }^{4}$ \\ 1,2,3,4 Yildiz Technical University, Electrical and Electronics Faculty, Electrical Engineering Department, Istanbul, Turkey \\ Email: $\left\{{ }^{1}\right.$ bkekez, ${ }^{2}$ hckiran, ${ }^{3}$ isengor, ${ }^{4}$ hakdemir\}@yildiz.edu.tr
}

\begin{tabular}{|c|c|}
\hline & lbstract \\
\hline $\begin{array}{c}\text { Keywords } \\
\text { Wind Turbine; } \\
\text { Lightning Protection; } \\
\text { Turbine Design }\end{array}$ & $\begin{array}{l}\text { Among renewable energy sources, wind energy has drawn a great attention in last decade. Wind } \\
\text { turbines are usually installed at places with high altitudes because of the nature of the wind. In addition } \\
\text { to this, wind turbines have sharp blades. Due to these two features of wind turbines, they can be } \\
\text { exposed to lightning. Hence, lightning protection of wind turbines is a critical subject. In this study, an } \\
\text { educational kit is designed to demonstrate the lightning protection methods of wind turbine. By using } \\
\text { this kit, different receptor, conductor or types of placement of conductor can be examined. In this study, } \\
\text { design steps of the kit is presented in details. The educational kit is also tested under artificial lightning } \\
\text { which are generated in the high voltage laboratory and measurement results are presented. The } \\
\text { education kit is also used by students in a laboratory course to understand lightning protection of a } \\
\text { wind turbine. }\end{array}$ \\
\hline
\end{tabular}

\section{Rüzgâr Türbinlerinin Yıldırımdan Korunması için Bir Eğitim Setinin Tasarlanması}

\begin{abstract}
Özet
Yenilenebilir enerji kaynakları arasında son on yılda rüzgâr enerjisi büyük bir ilgi görmüştür. Rüzgâr türbinleri genellikle rüzgârın doğası nedeniyle yüksek rakımlı yerlere kurulurlar. Buna ek olarak, rüzgâr türbinleri keskin rotor kanatlarına sahiptir. Rüzgâr türbinlerinin bu iki özelliği nedeniyle rüzgâr türbinlerinin yıldırıma maruz kalma riskleri yüksektir. Bu nedenle rüzgâr türbinlerinin yıldırımdan korunması kritik bir konudur. Bu çalışmada, bir eğitim seti rüzgâr türbininin yıldırımdan korunma yöntemlerini göstermek üzere tasarlanmıştır. Bu seti kullanarak, farklı toplayııı tipleri, iletken tipleri veya iletkenlerin yerleşim tipleri incelenebilir. Bu çalışmada, eğitim setinin tasarım aşamaları ayrıntılı olarak sunulmuştur. Eğitim seti, aynı zamanda yüksek gerilim laboratuvarında üretilen yapay yıldırım altında test edilmiştir ve ölçümler sunulmuştur. Eğitim seti, öğrencilerin bir rüzgâr türbininin yıldırımdan korunmasını daha iyi kavramaları için bir laboratuvar dersinde de kullanılabilir.
\end{abstract}

(C) Afyon Kocatepe Üniversitesi

\section{Introduction}

Significance of wind energy has been increased in the last decade because of carbon emission problems and non-renewable characteristics of fossil fuels. Therefore, various wind energy courses and programs related to wind energy have been organized in most of university all around the world. Wind energy is a multi-disciplinary field and related to almost all engineering areas. Because of wind energy technologies are related to several engineering principles, it is difficult for engineers to be familiar with the advancing of wind energy technologies. Hence a well-organized laboratory environment is necessary to teach the wind energy technologies for a good vocational background.

Researchers spent particular attention on lightning protection of wind turbine issue by conducting both theoretical and experimental studies. Some of these researches analysis in detail the actual wind turbines and its components with experimental results (Wen et al. 2016 and Yokoyama 2013), while the others utilize a small scaled prototype to 
evaluate the lightning protection of wind turbines (Yamamoto et al. 2007, Yamamoto et al. 2009 and Radicevic et al. 2013).

The performance of 5 different receptor types for lightning protection of wind turbine blades is analyzed by (Wang et al. 2017). Wind turbine blade attachment performance has been observed for 3 different receptor types are used namely; discrete receptor, discrete receptor with diverter string and, metallic tip in high voltage laboratory in (Montaya et al. 2010).

Several types of protection are tested in laboratory environment in (Arinaga et al. 2006), for clarifying some effects of components on lightning protection such as blade altitude, discharge polarity, receptor's shape, and size etc. An experimental environment is built to illustrate lightning damage on a rotor blade of wind turbine in (Yokoyama, 2011). Since wind turbine rotor blades can rotate, blade samples with receptor are tested in different angular positions. The arc paths and puncture position depending on the blade position during rotation is investigated by (Yan et al. 2017).

(Hansen et al. 2012) carried out analyzes from lightning protection of electrical components of the wind turbines. The assessment of lightning protection of wind turbine is realized using measurement data by (Peesapati et al. 2010). Furthermore, the lightning protection techniques for new generation turbin blades is addressed by (Rachidi et al. 2008). A study is also presented by (Cotton et al. 2001) which covers the lightning protection of wind turbine blades.

In this study, a laboratory kit designed by Electrical Engineering Department of Yildiz Technical University is introduced. The department presents a wide range of course options. So far, feedbacks which are taken from engineering students show that students can be easily motivated in the laboratory environment. Also feedbacks indicate that the courses enhanced with laboratory are more instructive and challenging for the students. In the light of these reasons, a wind turbine demonstration kit has been designed to teach the lightning protection of wind turbines. The education kit provides a detailed information about lightning protection types which are used in actual wind turbines. Also by using this kit, students can carry out experiments to test the lightning protection of wind turbines.

The rest of paper is organized as follow: Next section explains the designing steps of educational kit in details. A further section presents proposed experiments using this educational kit and gives an example about implemented in high voltage laboratory. Last section is the conclusion part including summary of the paper and evaluation of its contributions to engineering education.

\section{Design Studies}

In this study, an educational kit based on the requirements of IEC 61400-24 standard is designed to demonstrate wind turbine lightning protection systems in laboratory environment. The general view of education kit is illustrated in Figure 1.

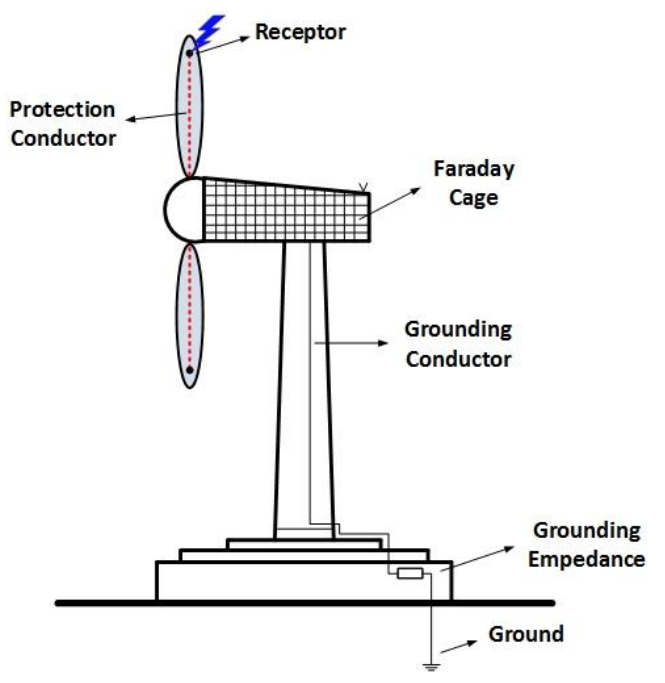

Figure 1. Overall picture of educational kit

The educational kit allows to analyze all types of protection systems used in actual wind turbines. Design process is divided into three steps: design of blade protection, design of hub protection, and design of grounding system, which are explained below. The educational kit is tested by generating lightning using high-voltage laboratory infrastructure. 


\subsection{Integration of Conductor to the Blades}

Assuming the rest of parameters e.g. air discharge level, etc., are same for all points of structure, the first contact point between lightning strike and any structure is generally expected to be the tallest point of the structure which is the easiest way for lightning discharge. As for the wind turbine applications, rotating blades are always the highest point of wind turbines. This is the reason for designing the blades as they should convey the lightning current to the ground. It should be noted that the lightning protection system of the wind turbine should not deteriorate the blade aerodynamic.

In this study, 5833 type of blade, which is designed by National Renewable Energy Laboratory (NREL), is used. Conductor path is opened on composite reinforced fiber blades of which length is $30 \mathrm{~cm}$. Being easy to shape material is the main reason for choosing the composite reinforced blade. Other parameters of this blade can be listed as: angle of attack is $10^{\circ}$, torsional angle is $2^{\circ}$ and taper ratio is 0.414. In order to preserve blade aerodynamic the conductor path is closed after the installation. The blades are embed in hub for demonstration of the different types of lightning protection. In this design, blades are locked into the hub via a hub cover.

The conductors' types and the ways of placement of the conductors on blades are determined according to standard IEC 61400-24. Although conductor material has no influence on protection efficiency, three different conductor materials that are stated in standard IEC 61400-24, namely, aluminum, copper, and brass are used. Accordingly, the protection conductor with a receptor is placed on the surface of blades as shown in Figure 3. According to the same standard; copper, steel and aluminum can also be used as a protection conductors on blades. In this educational kit, all standard definitions are implemented.

In the light of this standard several protection schemes of wind turbines can be tested using this kit. To carry out this purpose, blades are equipped with conductors. In Figure 2, blades equip with six different conductor can be seen. Blade names and features can be listed as:

1. Aluminum conductor is wrapped around the blade

2. Copper conductor is wrapped around the blade

3. Aluminum conductor is mounted inside the blade

4. Copper conductor is mounted inside the blade

5. Brass conductor is mounted inside the blade

6. Aluminum string is mounted inside the blade

It is expected that the lightning current goes directly into rotor hub after rotor blade. General application in the wind turbines is to integrate rotor blades and generator shaft to rotor hub. Apparently, conductors inside the blades rotate with the blades during the wind turbine operation. This is a challenging situation for the fixed grounding system. Therefore a ring conductor is mounted onto rotor hub and it is coupled with the rotor blades. By using conductive brush which is exist in grounding system of wind turbine, the lightning current is conveyed from rotating rotor hub to grounding conductor. At this point, isolation must be provided carefully because generator shaft and rotor blades are connected to rotor hub.
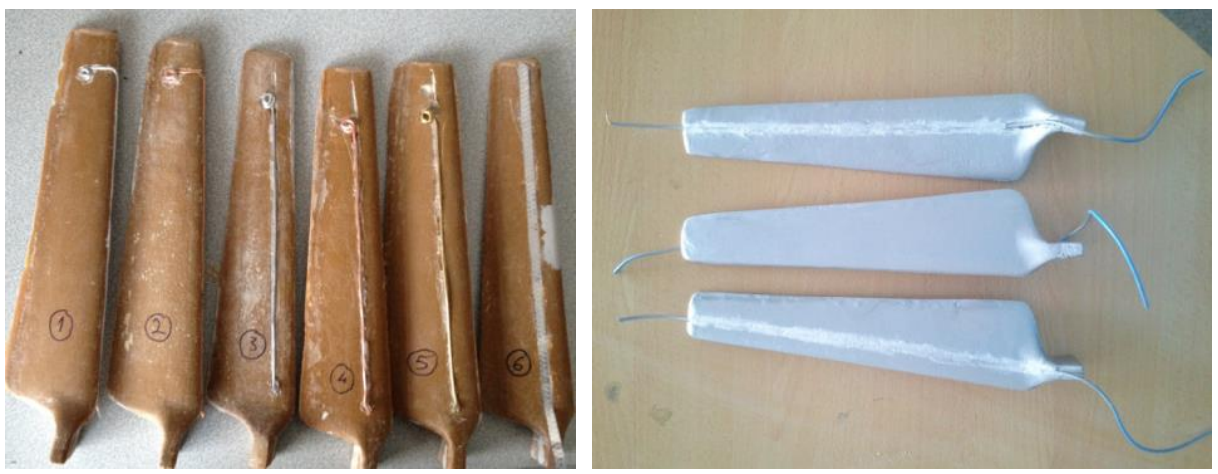

Figure 2. Conductor mounted blades (left), Painted blades (right) 
A possible isolation problem would cause tremendous damage on wind turbine. In the scope of this purpose, lubricated sponge whose puncture resistance is $30 \mathrm{kV}$, is used as isolation material. In Figure 3 , it can be seen that inner space of the hub equipped with Faraday cage.

In actual wind turbine applications, lightning strike can occur during the normal operation of wind turbines. Therefore, a DC motor unit is added into kit to illustrate rotation of blades. Thus, operation of protection types under different rotating speeds can be observed by using DC motor driver. In order to control rotation speed of blades DC motor is chosen because taking the advantage of its easy control feature. In designed educational kit, DC motor drives the rotor blades without a gear box. Hence, mechanical shaft speed of DC motor is equal to blade rotation speed. So, blade speed can be controlled by adjusting mechanical speed of DC motor. In Figure 4, DC driver scheme is shown. In this circuit, transformer decreases $220 \mathrm{~V}$ to $10 \mathrm{~V}$. Then, AC current is converted into DC current via uncontrolled full-wave rectifier. To adjust mechanical speed of DC motor, DC motor stator voltage must be changed. In this purpose, a variable resistor which is able to change resistor variable that is seen by the NE555, is used. Thus, this driver circuit can adjust input voltage of DC motor to the desired value. The specifications of circuit components are summarized in Table 1.

Table 1 Specifications of Control Circuit Components

\begin{tabular}{cccc}
\hline $\begin{array}{c}\text { Component } \\
\text { Name }\end{array}$ & Specification & $\begin{array}{c}\text { Component } \\
\text { Name }\end{array}$ & Specification \\
\hline D1, D2, D3, D4 & 6 A10 KT & C1 & $470 \mu \mathrm{F}$ \\
\hline D5, D6, D7 & $1 \mathrm{N4148}$ & C2 & $47 \mathrm{nF}$ \\
\hline R1, R2 & $10 \mathrm{k} \mathrm{ohm}$ & C3 & $10 \mathrm{nF}$ \\
\hline R3 & $\begin{array}{c}\text { 100k ohm } \\
\text { Variable Res. }\end{array}$ & Transistor & BD909 \\
\hline R4 & 200 ohm & & \\
\hline
\end{tabular}

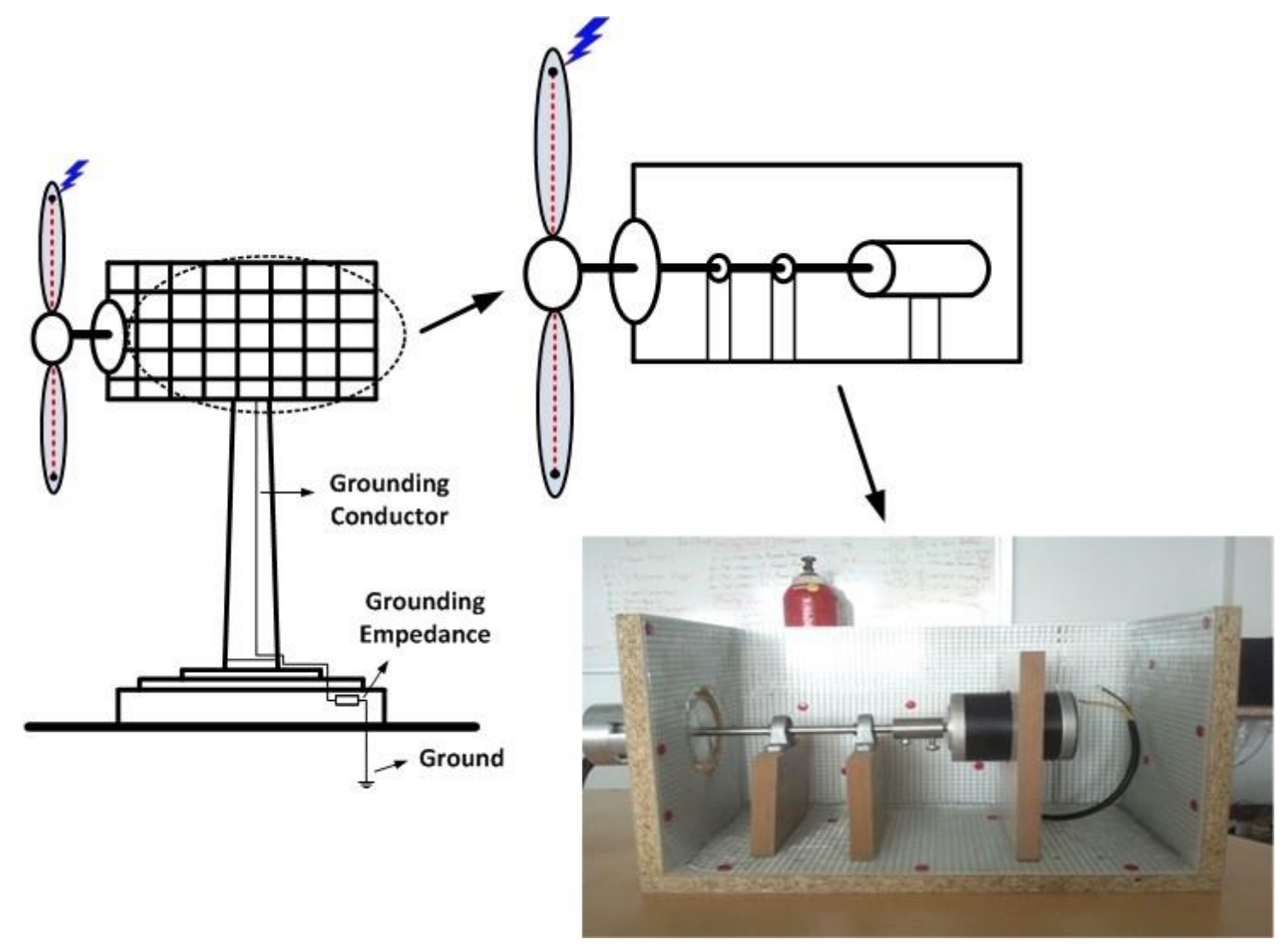

Figure 3. Insulation and brush 


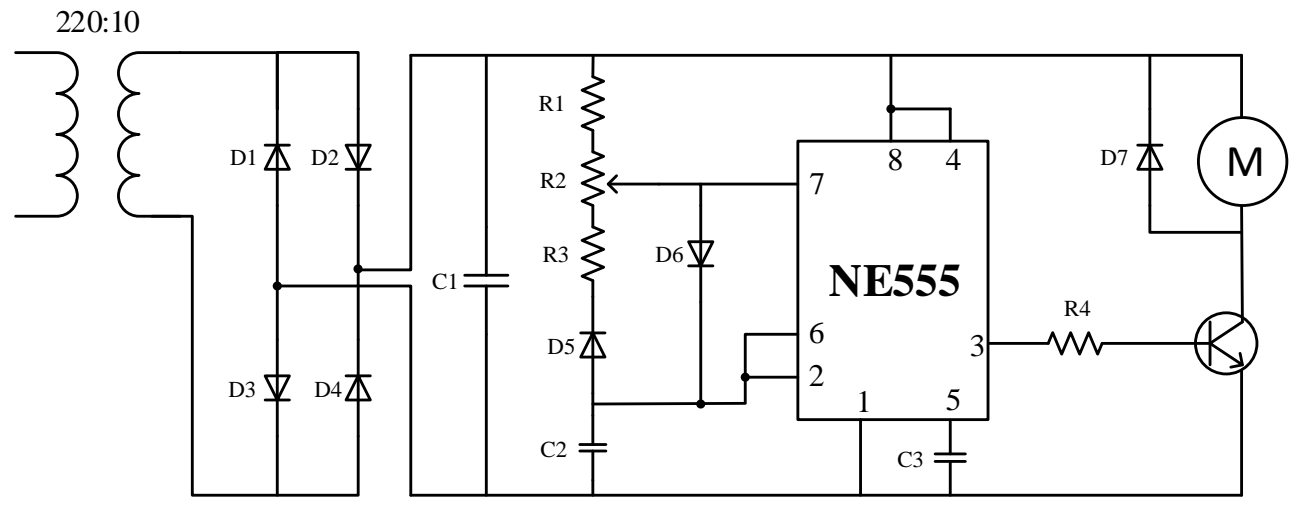

Figure 4. DC motor driver circuit

\subsection{Protection of Nacelle}

The main purpose of designed laboratory equipment is to protect internal devices of the wind turbine from possible damages due to the lightning. Hence, a mini prototype of the actual equipment are designed to demonstrate the real operating condition of the wind turbine during lightning strike. For this purpose, regarding the DC motor has the same electrical characteristic with a generator in case of lightning, it is used in Nacelle model. This feature of model is important because rotational speed of blade directly affects connection point and intensity of lightning strike. As a result, real operating conditions for lightning strike can be emulated at different speeds. Therefore, it is possible to get more accurate results can be obtained by making experiments at different speeds.
The turbine can be exposed to side flashes due to the height of the turbine, therefore an air termination system on the top of the nacelle may be insufficient to protect the nacelle. To eliminate this possibility, it is recommended that encircles interior of the nacelle like a Faraday cage in the standard of IEC 61400-24.

In this study, Faraday cage is mounted inner surface of the Nacelle to protect the equipment from the effect of lightning strike such as electromagnetic and physical damages. The cage is consist of $36 \mathrm{~mm}^{2}$ meshes and is able to transmit the lightning current to the ground over a connection cable with diameter of $1.5 \mathrm{~mm}^{2}$. Therefore, equipment which are inside of the nacelle is protected from lightning effects. It should be stated that the protection against higher voltage values can be provided by reducing the area of each mesh.

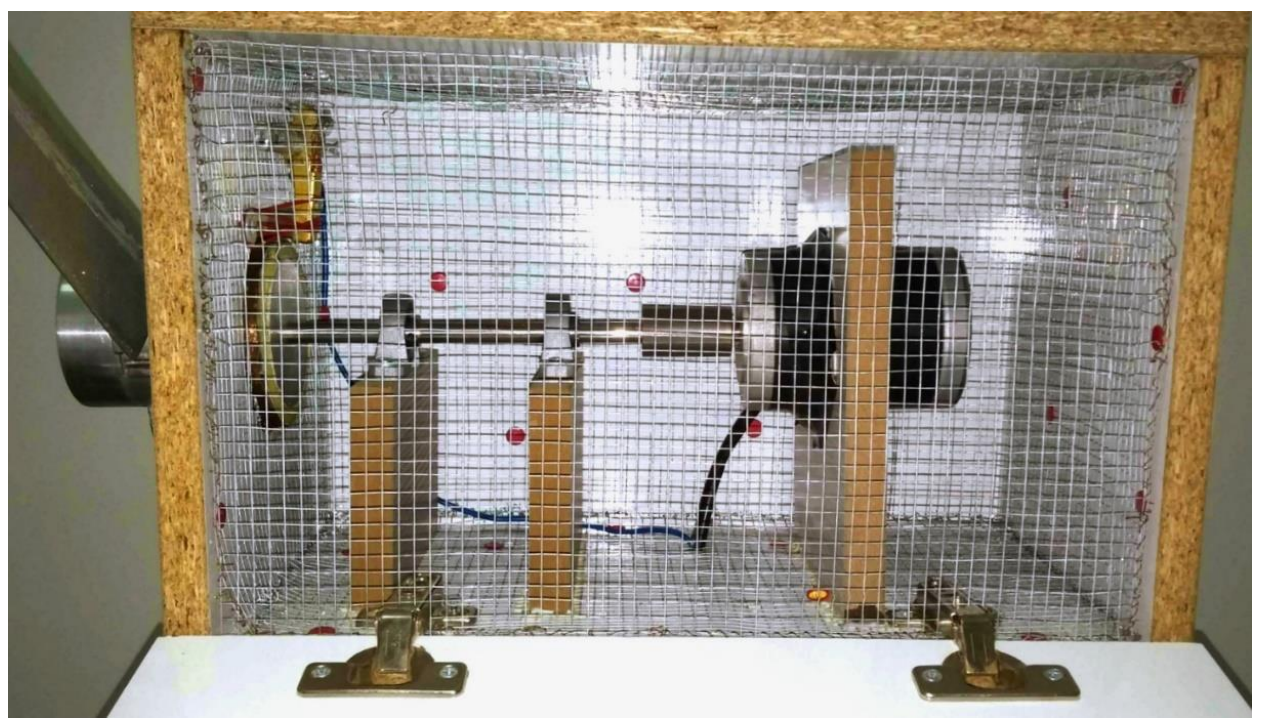

Figure 5. Nacelle Protection 


\subsection{Grounding System}

One of the most essential issue of lightning protection system is to form the most convenient grounding system using adequate grounding equipment. Therefore, this educational kit also allows to analyze wind turbine grounding conductor and grounding impedance. The educational kit provides an option for changing the grounding impedance to observe its effect on lightning protection system.

Outer rotor surface at the junction point of rotor blades and nacelle is surrounded by a conductor. Also, the conductor contact a coal which is placed in nacelle as can be seen from Figure 6 . The grounding conductor is connected to the coal in order to carry the lightning current in case of necessity.

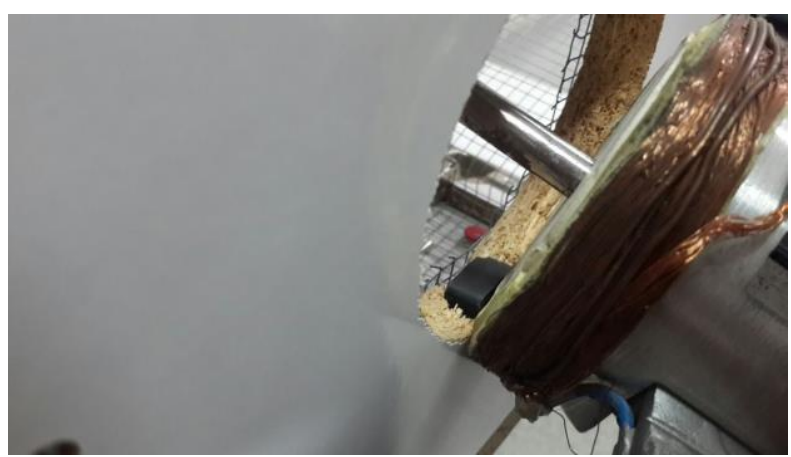

Figure 6. Grounding system of rotating parts

The final version of the educational kit which is constructed as a result of design process in three steps, can be seen from Figure 7 .

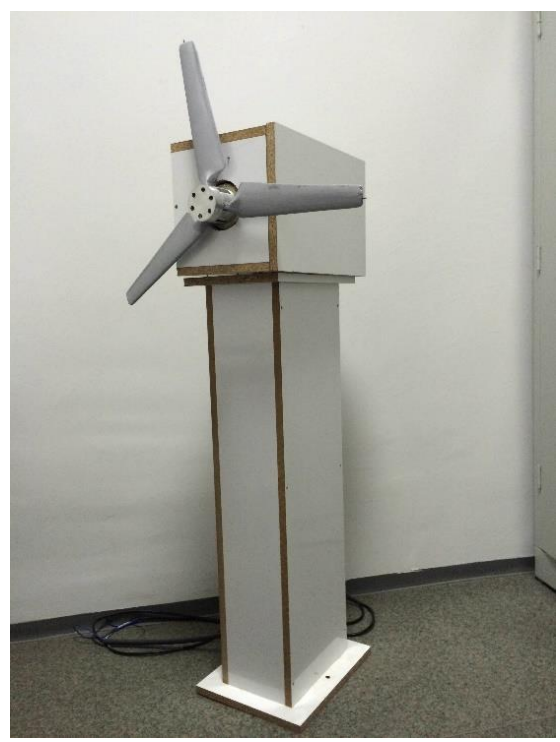

Figure 7. Overall Look of the Educational Kit

\section{Proposed Experiments}

The education kit is developed for illustration of wind turbine characteristic in the laboratory in case of lightning strike on the blades. Hence, several experiments which can be combined according to education level of students, are planned. . Experiments are listed as follows:

- Investigation of system during rotation

- Effect of location of down conductor

- Effect of receptor types

- Effect of grounding resistance

- Function of nacelle protection system

This developed set is suitable for application of various experiments. Different structures and placements of the receptors and behaviors of different protection conductor structures are examined. In this context, the different protection schemes of blades shown in Table 2 were tested in High Voltage Laboratory.

Table 2 . The features of tested blade types.

\begin{tabular}{cccc}
\hline $\begin{array}{c}\text { Blade } \\
\text { Type }\end{array}$ & Materials & $\begin{array}{c}\text { Types of Placement } \\
\text { of Protection } \\
\text { Conductors }\end{array}$ & Receptor Types \\
\hline Type $\mathbf{1}$ & Aluminum & Wrapped Around & Upper Middle \\
\hline Type $\mathbf{2}$ & Copper & Wrapped Around & Upper Middle \\
\hline Type $\mathbf{3}$ & Aluminum & Mounted Inside & Upper Middle \\
\hline Type $\mathbf{4}$ & Copper & Mounted Inside & Upper Middle \\
\hline Type $\mathbf{5}$ & Brass & Mounted Inside & Upper Middle \\
\hline Type $\mathbf{6}$ & Aluminum & Mounted Outside & Tip Blade \\
\hline
\end{tabular}

In Table 3, flashover voltage values and the discharge points can be seen. In all 6 cases, the blade angles are fixed to 50 degrees with respect to the vertical axis.

Table 3. Measured flashover voltage values and discharge points for different blade types.

\begin{tabular}{ccc}
\hline Blade Types & $\begin{array}{c}\text { Flashover } \\
\text { Voltage }(\mathbf{k V})\end{array}$ & Discharge Points \\
\hline Type 1 & 81 & Receptor \\
\hline Type 2 & 65 & Receptor \\
\hline Type 3 & 67 & Receptor \\
\hline Type 4 & 71 & Middle Point \\
\hline Type 5 & 67 & Under The Receptor \\
\hline Type 6 & 80 & Middle Point \\
\hline
\end{tabular}

In the other phase of the experiment, flashover voltage values and discharge points are analyzed in case of different positions of blade for a single protection structure type. The acquired results were 
shown in the Table 4. Different discharge moments during the experiment can be seen from Figure 8.

The results show aluminum conductor is the best conductor for the blade protection. From case 1 and case 3 , it can be seen that receptor catches the lightning regardless of whether it is mounted inside or wrapped around the blade. In addition, case 1 and case 6 show that receptor is not a discharge point when aluminum is mounted outside of the blade, although flashover voltages are nearly same.
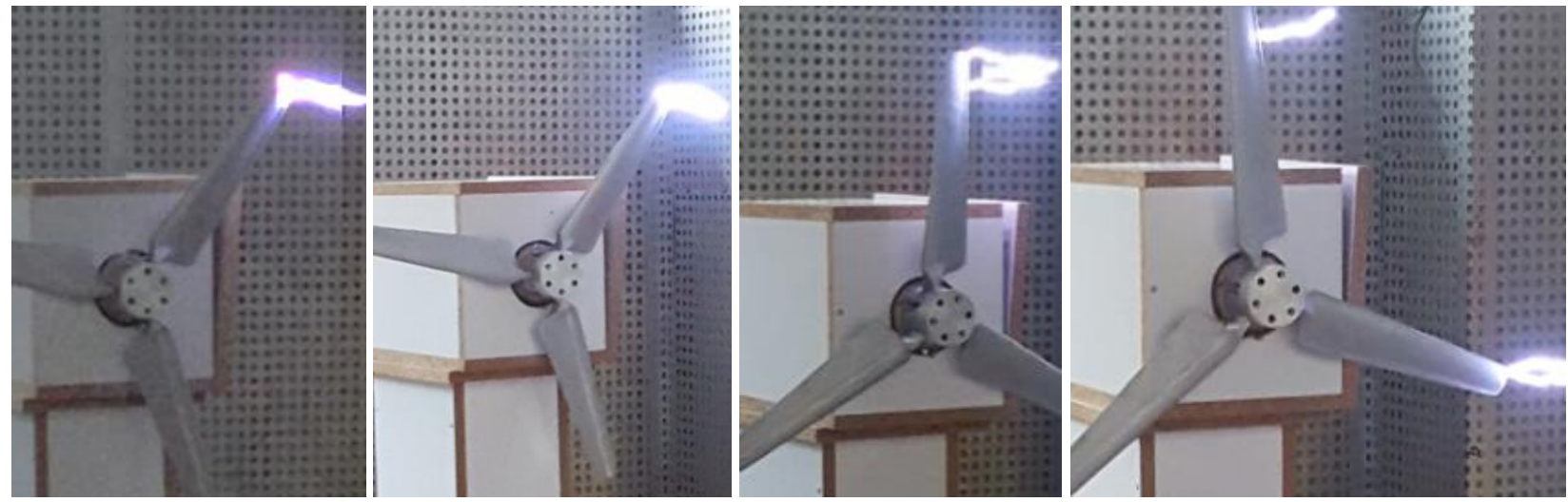
points for different pitch angle of blade type 5 .
Figure 8. Discharge moments during the experiments

Table 4. Measured flashover voltages and discharge

\begin{tabular}{ccc}
\hline & \multicolumn{2}{c}{ Type 5 } \\
\hline Pitch Angle & Flashover Voltage (kV) & Discharge Points \\
\hline $\mathbf{5 0}$ & 67 & Receptor and 2 cm down \\
\hline $\mathbf{6 0}$ & 55 & Receptor \\
\hline $\mathbf{7 0}$ & 44 & Receptor \\
\hline $\mathbf{8 0}$ & 28 & Receptor \\
\hline $\mathbf{9 0}$ & 21 & Receptor \\
\hline
\end{tabular}

In copper conductor cases, receptor performs properly when conductor is wrapped around the blades and flashover voltage is $65 \mathrm{kV}$. On the other hand, when the flashover voltage is $75 \mathrm{kV}$ and conductor is mounted inside of the blade, receptor missed the lightning. Therefore, it can be concluded that when flashover voltage is higher, blade damage risk increases. Finally, when types of placement of conductor and flashover voltage levels are the same as in case 3 and case 5 , aluminum conductor protects the blade while the brass does not.

Brass type conductor is also tested for different angles of blade. Table 4 summarizes flashover voltages and discharge points for this case. The results show that flashover voltage is lower when blade tip is at highest position. Therefore, it can be deduced that the lightning is more likely to occur in this case. Additionally, the highest flashover voltage is observed when the blade angle is 50 degree. In this case, flashover voltage is $67 \mathrm{kV}$ and receptor could not protect the blade.

\section{Conclusion}

In this study, a laboratory kit was designed and tested about the lightning protection of wind turbine system. Different protection structures such as receptor types, structure and geometry of conductors, hub protection system and grounding system were analyzed and evaluated with the laboratory kit. Six different experiments were carried out using the kit and this can be increased by using different combinations. Students can examine a real lightning protection system of a wind turbine physically by using this prototype.

In this paper, all of the experiments were carried out with standing still blades at different blade angles. It would be interesting to carry out the same experiments with rotating blades and compare the results with standing still ones, which is regarded as a future work by the authors.

\section{Acknowledgement}

The authors would appreciate the laboratory team for their valuable support. 


\section{References}

Arinaga, S., Inoue, K., \& Matsushita, T., 2006. 'Experimental Study For Wind Turbine Blades Lightning Protection' in International Conference and Exhibition, Makuhari Messe Chiba, Japan.

Cotton, I., Jenkins, N., \& Pandiaraj, K., 2001. Lightning protection for wind turbine blades and bearings. Wind Energy, 4(1), 23-37.

Hansen, A. N., Erichsen, H. V., \& Politis, Z. G., 2012. Lightning Protection of the Electrical Systems of WTG: Evaluation Considerations Related to the Application of SPDs. In Lightning Protection (ICLP), 2012 International Conference on. 1-6. IEEE..

IEC 61400-24: 2002, Wind turbine generator systems Part 24: Lightning protection.

Montanyà, J., March, V., Hermoso, B., \& Hermoso, J. R., 2010. High-speed videos of laboratory leaders emerging from wind turbine blade tips. In Lightning Protection (ICLP), 2010 30th International Conference on (pp. 1-5). IEEE.

Peesapati, V., Cotton, I., Sorensen, T., Krogh, T., \& Kokkinos, N., 2011. Lightning protection of wind turbines-a comparison of measured data with required protection levels. IET renewable power generation, 5(1), 48-57.

Rachidi, F., Rubinstein, M., Montanya, J., Bermudez, J. L., Sola, R. R., Sola, G., \& Korovkin, N., 2008. A review of current issues in lightning protection of newgeneration wind-turbine blades. IEEE Transactions on Industrial Electronics, 55(6), 2489-2496.

Radičević, B. M., Savić, M. S., Madsen, S. F., \& Badea, I., 2012. Impact of wind turbine blade rotation on the lightning strike incidence-A theoretical and experimental study using a reduced-size model. Energy, 45(1), 644-654.

Wang, Y., \& Hu, W., 2017. Investigation of the Effects of Receptors on the Lightning Strike Protection of Wind Turbine Blades. IEEE Transactions on Electromagnetic Compatibility, 59(4), 1180-1187.

Wen, X., Qu, L., Wang, Y., Chen, X., Lan, L., Si, T., \& Xu, J., 2016. Effect of wind turbine blade rotation on triggering lightning: An experimental study. Energies, 9(12), 1029
Yamamoto, K., Noda, T., Yokoyama, S., \& Ametani, A., 2007. An experimental study of lightning overvoltages in wind turbine generation systems using a reducedsize model. Electrical Engineering in Japan, 158(4), 22 30.

Yamamoto, K., Noda, T., Yokoyama, S., \& Ametani, A., 2009. Experimental and analytical studies of lightning overvoltages in wind turbine generator systems. Electric Power Systems Research, 79(3), 436-442.

Yan, J., Li, Q., Guo, Z., Ma, Y., Wang, G., Zhang, L., \& Yan, J. D., 2017. Puncture position on wind turbine blades and arc path evolution under lightning strikes. Materials \& Design, 122, 197-205.

Yokoyama, S., 2011. Lightning protection of wind turbine generation systems. In Lightning (APL), 2011 7th AsiaPacific International Conference on. 941-947. IEEE.

Yokoyama, S., 2013 , Lightning protection of wind turbine blades, Electric Power Systems Research, 94, 3-9. 